\title{
Morphological and molecular evidence support description of two new dia- tom species from the genus Ulnaria in Lake Baikal
}

\author{
Maxim Kulikovskiy ${ }^{1 *}$, Horst Lange-Bertalot ${ }^{2}$, Natalia Annenkova ${ }^{3}$, Evgeniy \\ GuSEV $^{1} \&$ John Patrick KocioleK ${ }^{4,5}$
}

\author{
${ }^{1}$ Papanin's Institute for Biology of Inland Waters Russian Academy of Sciences \\ Russia, 152742 Yaroslavl, Nekouz, Borok; *Corresponding author e-mail: max-kulikovsky@yandex.ru \\ ${ }^{2}$ Department of Palaeoceanology, Institute of Marine Sciences, University of Szczecin, Mickiewicza 18, PL- \\ 71415 Szczecin, Poland \\ ${ }^{3}$ Limnological Institute Siberian Division, Russian Academy of Sciences, Ulan-Batorskaya 3, RUS-664033, \\ Irkutsk, Russia \\ ${ }^{4}$ Museum of Natural History and ${ }^{5}$ Department of Ecology and Evolutionary Biology University of Colorado, \\ Boulder, Colorado, 80309 USA
}

\begin{abstract}
Light and scanning electron microscopical observations are made on two non-raphid pennate species from Lake Baikal, Russia. Based on their morphologies, they are assigned to the genus Ulnaria. Molecular data from $r b c \mathrm{~L}$ sequences were also generated from cultures of these two taxa. Combined morphological and molecular data suggest one of the species is the same as a species commonly referred to as Synedra acus, a species commonly reported from Lake Baikal and used as a model species for studies on valve silicification and nanotechnology applications. The second species is similar to Ulnaria ulna. Both taxa are important players in the ecology of Lake Baikal. Based on the combined molecular and morphological approach, and comparison of the species with recently designated types for both $U$. ulna and $U$. acus, we conclude that the two species are not synonymous with either $U$. acus or $U$. ulna, or other known species, and present full descriptions of them as species new to science.
\end{abstract}

Key words: ancient lakes, diatoms, Lake Baikal, morphology, new species, phylogeny, Ulnaria

\section{INTRODUCTION}

Lake Baikal is a hotspot of endemic diatoms (KULIKOVSKIY et al. 2012b, 2015b; KULIKOVSKIY \& KOCIOLEK 2014; VishnYAKOv et al. 2014). Comprehensive study of diatoms from this lake reveals remarkable taxonomic diversity, and a few hundred new species were described (Kociolek et al. 2013; KULIKOVSKIY et al. 2011, 2012a,c, 2013, 2014a,b, 2015a). These investigations relate to our understanding of species diversity in the benthic diatom community. Planktonic diatoms were studied previously and data about their diversity were summarized in Popovskaya et al. $(2002,2011)$. These authors described planktonic diatom communities in Lake Baikal, including centric diatoms (Aulacoseira Thwaites, Cyclotella (KützIng) BRÉBISson and Stephanodiscus EHRENBERG), non-raphid pennate taxa from the genera Fragilaria Lyngbye, Synedra Ehrenberg, Asterionella Hassall, Hannaea PATRICK, Diatoma Bory, Meridion Agardh, Tabellaria Ehrenberg, and Belonastrum (Lemmermann) Round et Maidana, and the raphid genera Nitzschia Hassall and Cymatopleura Sмith (Popovskaya et al. 2002, 2011).

Recently there has been a revision of the planktonic species in the genera Fragilaria and Ulnaria (KützING) COMPÈRe, including the typification of several species (LANGe-Bertalot \& UlRich 2014). Species of the non-raphid pennate genus Ulnaria play important roles in phytoplankton communities of Lake Baikal (PopovsKayA et al. 2002, 2011). They dominate in some years generating so-called "Synedra years" versus centric diatom-dominated assemblages ("Aulacoseira years") (PopovskAYA \& GENKAL 1998). Previously all Ulnaria species were included to the large genus Synedra (Compère 2001). SKABITSCHEwSKy (1960) was the first to prepare a revision of planktonic diatoms from Lake Baikal. PopovskAYA et al. (2002, 2011) fully accepted his opinion about taxonomic diversity for this group of diatoms in the lake. These authors reported four taxa, and in terms of currently accepted taxonomic position, these four taxa would be assigned to the genus Ulnaria, but commonly they are referred to as: 
Synedra acus KützING, S. acus var. radians (KüTZING) Hustedt, S. ulna (Nitzsch) Ehrenberg, and S. ulna var. danica (KützIng) Grunow (SKabitschewsky 1960; PoPOVSKAYA et al. 2011). A word here about what could be confusion regarding the nomenclature of some of these taxa. SKABitchewsky (1960) commented that he preferred to use the designation "subspecies" versus variety. SKABITCHEWSKY did not intend to create new names with his designation of subsp., so we use the older trinomial for our designations of $S$. acus var. radians and S. ulna var. danica (var. instead of subsp.).

Members of the genus Ulnaria (under the name Synedra) from Lake Baikal have, for a long time, been used as model freshwater organisms for various studies due to their relatively easy cultivation. In particular, there are numerous studies about molecular biosilification mechanisms in vivo (GRACHEV et al. 2005; SAFONOVA et al. 2007; BASHARINA et al. 2012; ANNENKOV et al. 2013), design of new experimental approaches to study biosilification (ANNENKOv et al. 2010, 2013), and the role of the cytoskeleton in the morphogenesis of siliceous frustule (KHARITONENKO et al. 2015). The investigations help us in understanding chemical principles of silification and how such process occur in living cells. This knowledge contributes to various nanotechnological applications (Losic et al. 2009). Moreover $S$. acus is the first freshwater diatom with completely documented mitochondrial and chloroplast genomes (RAVIN et al. 2010; GALACHYANTS et al. 2012). Its interaction with bacterial community is also under investigation (ZAKHAROVA et al. 2010). Finally, given the importance of the non-raphid pennate planktonic diatoms to the ecosystem structure and function in Lake Baikal (HAMPTON et al. 2014), including their responses to climate and other anthropogenic environmental changes (MACKAY et al. 1998; MoOre et al. 2009), it becomes clear how important it is to identify the taxa correctly and communicate efficiently and effectively via biological names (DE QUEIROZ \& GAUTHIER 1994).

The aim of this work is to produce the first revision of planktonic diatoms from the genus Ulnaria, including combined molecular and morphological data, to understand the species occurring in Lake Baikal.

\section{Material ANd Methods}

Samples were collected from Lake Baikal by M.S. KulikovsKIY in July, 2012, and strains were isolated by E.S. GUSEV. Strains of Ulnaria ferefusiformis sp. nov. were isolated from the following samples: B114, B118 - plankton near Bolshoi Ushkaniy Island, 28.07.2012, 53 $51^{\circ} 129^{\prime \prime N}, 108^{\circ} 35^{\prime} 795^{\prime \prime E}$; B119 - plankton from Solnechnaya Bay, 29.07.2012, $54^{\circ} 17^{\prime} 327^{\prime \prime N}, 108^{\circ} 29^{\prime} 106^{\prime \prime E}$. Strains of Ulnaria pilum sp. nov. were isolated from the following samples: B155 plankton from Ludarskaya Bay, 30.07.2012, 55²2'429"N, $109^{\circ} 12^{\prime} 652^{\prime \prime E}$; B160 - plankton from Sludianskaya Bay, $30.07 .2012,55^{\circ} 28^{\prime} 078^{\prime \prime} \mathrm{N}, 109^{\circ} 09^{\prime} 828^{\prime \prime} \mathrm{E}$. Water temperature was about $17{ }^{\circ} \mathrm{C}$ and conductivity $111 \mu{\mathrm{S} . \mathrm{cm}^{-1}}^{-1}$ in studied places. Water mineralization and temperature measurements were performed using the Hanna Combo (HI 98129) device, Hanna Instruments, Inc., USA.

A subsample of each collection was added to WC liquid medium (GuILlard \& LORENZEN 1972). Monoclonal strains were established by micropipetting single cells under an inverted microscope. Nonaxenic unialgal cultures were maintained in WC liquid medium at $10{ }^{\circ} \mathrm{C}$ in a growth chamber with a $12: 12 \mathrm{~h}$ light/dark photoperiod.

Strains for LM and SEM investigations have been processed by means of a standard procedure involving, treatment with $10 \% \mathrm{HCl}$ and concentrated hydrogen peroxide. After treatment the sample was washed with deionized water. Permanent diatom preparations have been mounted in Naph$\operatorname{rax}^{\circledR}$. Light microscopic (LM) observations have been performed by means of a Zeiss Axiovert microscope equipped with oil immersion objective $(\times 100 /$ n.a.1.4, DIC). Valve ultrastructure was examined with a JSM-6510LV field emission scanning electron microscope (Borok, Russia).

Total DNA of monoclonal cultures was extracted using a NucleoSpin ${ }^{\circledR}$ Plant II Mini kit (Macherey-Nagel, Germany) according to the manufacturer's protocol. Fragments of partial $r b c \mathrm{~L}$ plastid genes (912 bp) were amplified using primers from ABARCA et al. (2014) for $r b c \mathrm{~L}$ fragments

For amplification of $r b c \mathrm{~L}$ we used reaction volumes of $25 \mu$, with $10 \mathrm{ng}$ of gDNA, $0.8 \mathrm{mM}$ of forward primer, $0.8 \mathrm{mM}$ of internal reverse primer, $3 \mathrm{mM} \mathrm{MgCl}_{2}, 0.5 \mathrm{M} \mathrm{Be}-$ taine monohydrate, $250 \mu \mathrm{M}$ dNTP, $10 \mathrm{mM}$ Tris- $\mathrm{HCl}, 50 \mathrm{mM}$ $\mathrm{KCl}, 2.5 \mathrm{nl}$ Tween 20 and 0.75 units of PeqLab Hot Taq DNA Polymerase. The conditions of amplification were: an initial denaturation of 2 min at $94{ }^{\circ} \mathrm{C}$, followed by 40 cycles at 94 ${ }^{\circ} \mathrm{C}$ for denaturation $(1 \mathrm{~min}), 52.8^{\circ} \mathrm{C}$ for annealing $(45 \mathrm{~s})$ and $72{ }^{\circ} \mathrm{C}$ for extension $(1.5 \mathrm{~min})$, and a final extension of $10 \mathrm{~min}$ at $72{ }^{\circ} \mathrm{C}$. (ABArCa et al. 2014).

The obtained sequences were edited manually and assembled using BioEdit v7.1.3 (HaLl 1999). Analysis of the genetic differences between the sequences was performed with MEGA v.6.1 (TAMURA et al. 2011). Newly determined sequences and DNA fragments from 50 other members of the group "clade II non-raphid pennate pennate diatoms, which were downloaded from GenBank (taxa and Accession Numbers are given in the tree, Fig. 31), were included in the alignment. Two raphid diatoms (Pinnularias) were chosen as outgroup. The alignment was constructed using Mafft v6.952 based on the G-INS-I model with default parameters (КАтоH $\&$ Tон 2010). Bayesian information criterion (BIC) implemented in jModelTest 2.1.1 (DARRIBA et al. 2012) indicated, that the General Time Reversible (GTR) model of nucleotide substitution, with Gamma $(G)$ distributed rates across sites and a proportion of invariable sites (I) was the most appropriate evolutionary model for the $r b c \mathrm{~L}$ DNA alignment. Phylogenies of these sequences were constructed based on this model using Bayesian inference (BI) and Maximum Likelihood (ML) analysis.

BI analysis was conducted with MrBayes-3.1.2 (RoNQUist \& HUELSENBECK 2003) and was run with 5 Markov chains (four heated chains, one cold) for $2 \cdot 106$ generations and 2 independent runs in each analysis. Trees were sampled every 100 th generation, the first $25 \%$ samples were discarded as "burn-in". ML analysis was conducted using GARLI 2.0 on-line program (BAZINET \& CUMmIngs 2008). The tree was constructed with collapsing the branch into a polytomy. It is important when bootstrapping, since no support should be given to a branch that doesn't really exist. Subtree-pruningregrafting (SPR) first tree swapping algorithm and non-para- 
metric bootstrap analysis with 100 replicates were used. The statistical support values were drawn on the ML tree visualized using iTOL (http://itol.embl.de/).

Sequences from Ulnaria obtained in this study were deposited to GenBank under following Accession Numbers Ulnaria pilum strain B155 (KR336759), Ulnaria pilum strain B160 (KR336760), Ulnaria ferefusiformis strain B114 (KR336761), Ulnaria ferefusiformis strain B118 (KR336762), Ulnaria ferefusiformis strain B119 (KR336763)

\section{Results AND Discussion}

\section{Formal descriptions of new species}

Ulnaria ferefusiformis KuLIKovSKIY, LANGE-BERTALOT sp. nov. (Figs 1-13)

Description

Light microscopy (Figs 1-8): Valves approximately fusiform, i.e. weakly spindle-shaped, with parallel or slightly concave margins proximally slightly ca. halfway to the ends, then narrowing more strongly and finally tapering towards subcapitate ends. Length 76$152 \mu \mathrm{m}$, breadth proximally $4.0-4.8 \mu \mathrm{m}$, distally below the apices $0.7-1.2 \mu \mathrm{m}$, at apices $1.4-1.6 \mu \mathrm{m}$. Axial area very narrow distally, becoming wider proximally to ca. $0.3 \mu \mathrm{m}$. Central area somewhat indistinctly defined due to a more or less clear, but weak, ghost striae. Other striae in alternate or opposite position, 12-14, rarely up to 15 in $10 \mu \mathrm{m}$, becoming slightly more densely-spaced near the ends. Areolae not discernible.

Scanning electron microscopy (Figs 9-13): Areolae about 50 in $10 \mu \mathrm{m}$, lacking or reduced in number in the central area; distally strongly reduced to two, finally a single one on either side of the valve face and an additional one on valve mantles. Poles are covered by seriate pore fields (ocellulimbi); each pole with a large rimoportula internally. External opening of the rimoportula is a simple circular poroid. Marginal spines lacking.

Etymology: The Latin epithet means approximately spindle-shaped.

Type locality: Russia, Lake Baikal, sample B114 (5351'129"N, 108³5'795"E), leg. M. KuLikovsKiY, coll. date 28/07/2012.

Holotype (designated here): slide B114m (IBIW, Russia).

Iconotype: Fig. 3.

Ulnaria pilum Kulikovskiy, Lange-Bertalot sp. nov. (Figs 14-30)

Description

Light microscopy (Figs 14-24): Valves needle-shaped, tapering from the central part with almost parallel margins towards the ends, however not continually, since distal parts are drawn out, i.e. more strongly narrowed below the subcapitate apices. Length 218 $295 \mu \mathrm{m}$, breadth proximally $5.6-6.3 \mu \mathrm{m}$, subapically 2.0-2.2 $\mu \mathrm{m}$. Length-to-breadth ratio is ca. 40-50. Axial area very narrow, linear. Central area distinct, rectangular, variable in length, ghost striae scarce or missing. Striae $10.0-11.5$ in $10 \mu \mathrm{m}$; position predominantly opposite proximally, predominantly alternate distally. Areolae difficult to discern.

Scanning electron microscopy (Figs 25-30): Large ocellimbi are present on the mantle as are, two apical spines. Rimoportula are present at both poles, similar to most other taxa of the Ulnaria ulna cluster. Marginal spines lacking. Areolae 35-40 in $10 \mu \mathrm{m}$. Proximal striae of the valve face consist of 6-9 areolae, however distal striae have at most three or two areolae or a single areola on either side. Other features as described for U. baicalensis.

Etymology: The Latin pilum, in English javelin, was

Table 1. Measurements of main quantitative features of studied taxa.

\begin{tabular}{|c|c|c|c|c|}
\hline Taxon & $\begin{array}{l}\text { Length } \\
(\mu \mathrm{m})\end{array}$ & $\begin{array}{l}\text { Breadth } \\
(\mu \mathrm{m})\end{array}$ & $\begin{array}{l}\text { Striae } \\
\text { in } 10 \mu \mathrm{m}\end{array}$ & Resources \\
\hline Ulnaria ferefusiformis sp. nov. & $76-152$ & $4-4.8$ & $12-14$ & This study \\
\hline Synedra acus KüTzING & $90-300$ & $4.5-5$ & $12-14$ & SKABITSCHEWSKY 1960 \\
\hline Synedra acus KüTzING & $90-250$ & $4-5$ & $12-14$ & PoPOVSKAYA et al. 2002 \\
\hline Ulnaria pilum sp. nov. & $218-295$ & $5.6-6.3$ & $10-11.5$ & This study \\
\hline Synedra ulna var. danica (KÜTZING) GRUNOW & $89-480$ & $4.5-6.4$ & $8-11$ & SKABITSCHEWSKY 1960 \\
\hline Synedra ulna var. danica (KÜTZING) GRUNOw & $235-442$ & $8-10$ & $8-10$ & PopovsKaya et al. 2002 \\
\hline Synedra ulna var. danica (KÜTZING) GRUNOw* & - & 5.4 & 8 & POPOVSKAYA et al. 2002, 60: 2, 3 \\
\hline Synedra acus var. radians (KüTZING) HustedT & $200-500$ & $2-5$ & $12-18$ & SKABITSCHEWSKY 1960 \\
\hline Synedra acus var. radians (KÜTzING) HustedT & $142-288$ & $2.2-5$ & $11-22$ & PopOVSKAYA et al. 2002 \\
\hline Synedra acus var. radians (KüTzING HustedT & $142-288$ & $2.8-5$ & $11-18$ & Popovskaya \& GENKAL 1998 \\
\hline
\end{tabular}

* counted by us from pictures given in publications 
an important weapon of the infantry of the Roman Empire.

Type locality: Russia, Lake Baikal, sample B155 $\left(55^{\circ} 22^{\prime} 429^{\prime \prime N}, 109^{\circ} 12^{\prime} 652^{\prime \prime E}\right)$, leg. M. KuLikovskiY, coll. date 30/07/2012.

Holotype (designated here): slide B155m (IBIW, Russia).

Iconotype: Fig. 14.

\section{Phylogenetic analysis data}

All the $r b c \mathrm{~L}$ DNA fragments of the studied Ulnaria ferefusiformis strains were identical to each other and to the diatom named "Synedra acus", which was collected previously from Lake Baikal (GALACHYANTS et al. 2012) and had the same morphology (see below) as $U$. ferefusiformis sp. nov. Thus, with this correspondence between morphology and molecular sequence data it seems they are the same species. DNA fragment of Ulnaria ulna differs from them by $0.7 \%$ (nine substitutions). The two strains of Ulnaria pilum sp. nov. investigated here have identical $r b c \mathrm{~L}$ gene fragments, which clearly differ from partial $r b c \mathrm{~L}$ gene of $U$. ferefusiformis sp. nov. Both studied species were included in clade I (Fig. 31). Within that clade U. pilum sp. nov. forms one highly supported clade with two strains of U. ulna, U. ferefusiformis sp. nov. strains and "S. acus" from Baikal (Fig. 31, clade Ia). This Ulnaria-like clade forms one group with Fragilaria-like species with high statistical support (ML 74, BI 100, clade I). These species clearly differ from any known Synedra species according to the phylogenetic tree. It should be mentioned that the two strains of $U$. ulna, which were included in the analysis, did not cluster together. This can be explained because of biases (artefacts during sequencing, in particular Next Generation Sequencing of the strain TCC 520; KermarReC et al. 2013), wrong identification of one or both strains based on morphology, and / or the possibility of cryptic diversity within U. ulna.

The phylogenetic tree based on partial $r b c \mathrm{~L}$ gene includes members of non-raphid pennate diatoms and outgroup from the raphid diatoms (Pinnularia termitina (EHRENBERG) Fricke and Pinnulatia viridiformis KRAMMER). Within non-raphid diatoms four species from the genus Synedra formed a distinct, separate clade with high statistical support (100 ML; 100 BI, Figure 31, VI group). Other non-raphid diatoms belonged to one clade but with moderate support (ML 64, BI 97, Figure 31). Within this clade there are five relatively big and highly supported groups (I - V groups, Figure 31) and certain species outside them. The phylogenetic relations between I - V groups and other non-raphid diatoms from this study stay unresolved. Similar results were obtained in the previous studies (e.g., THERIOT et al. 2010). Investigations of both much more genetic data and diatom samples are needed for the identification of evolutionary relations between these non-raphid diatom genera. Anyway our

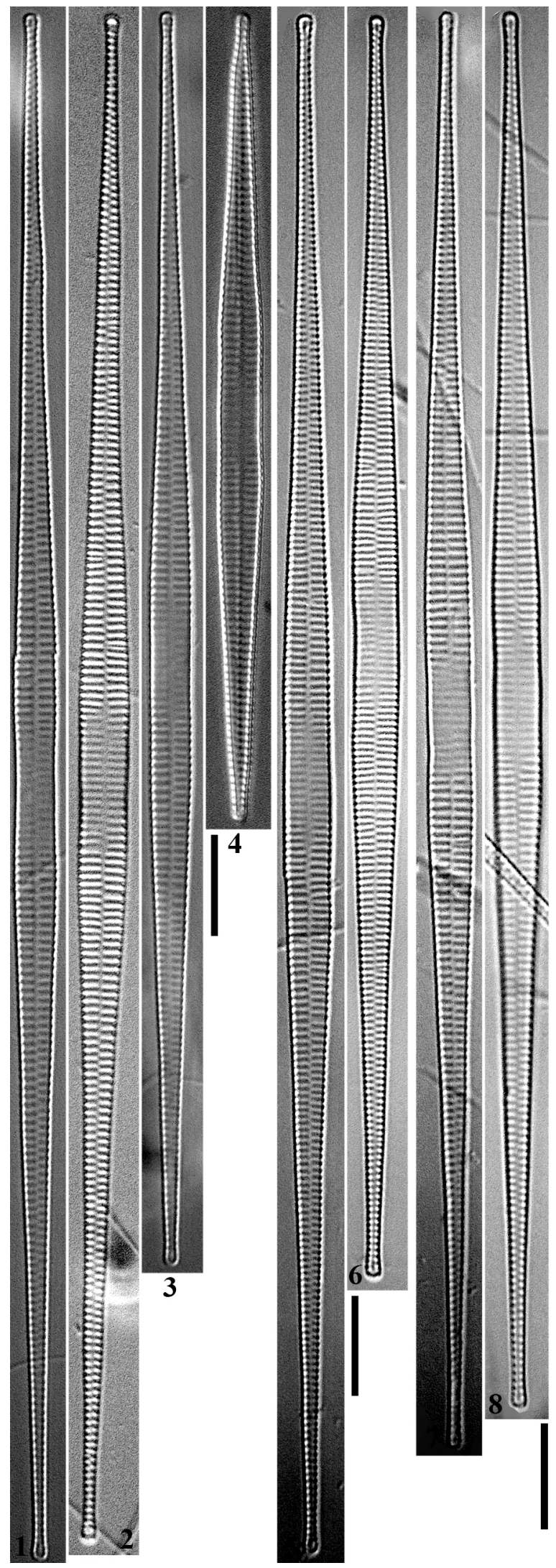

Figs 1-8. Ulnaria ferefusiformis sp. nov. LM: (1-4) valves from strain B114, (5-6) valves from strain B118, (7-8) valves from strain B119. Scale bars $10 \mu \mathrm{m}$. 

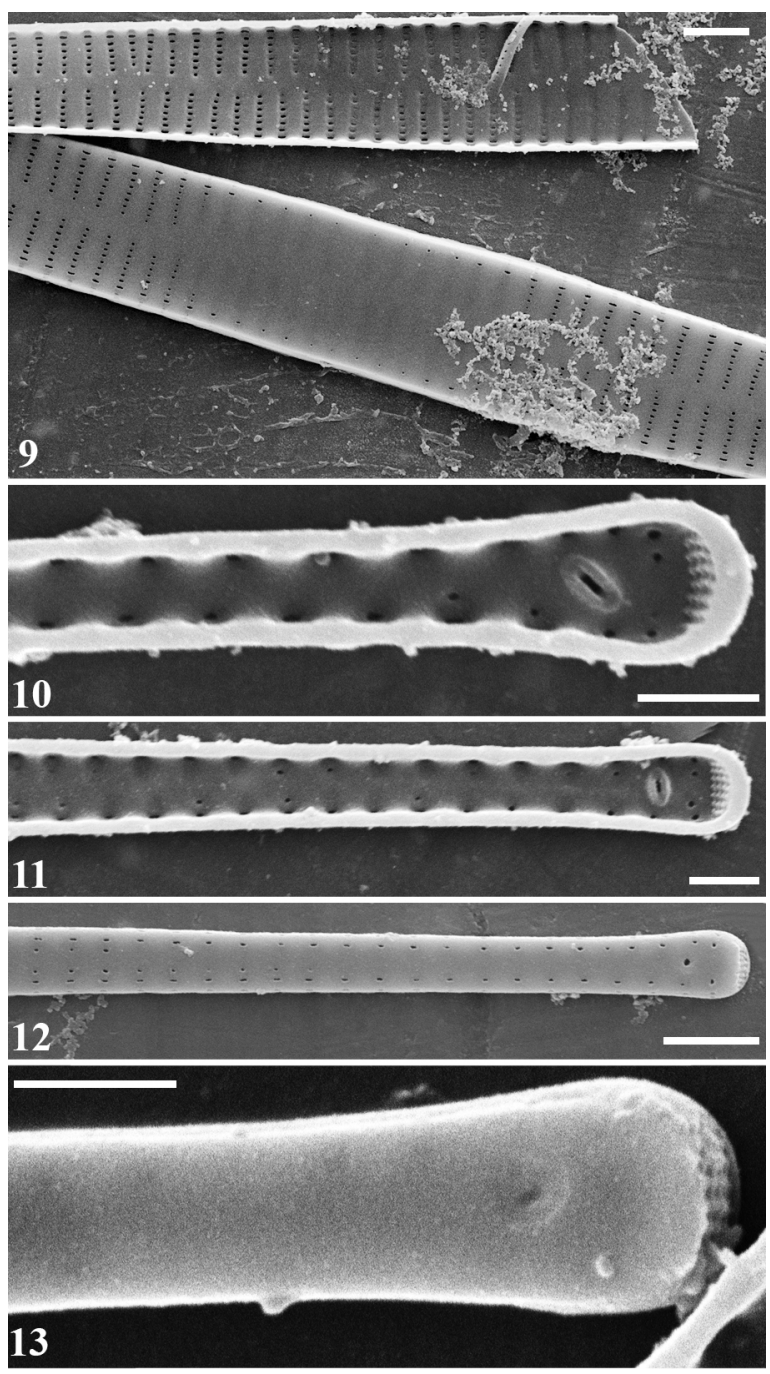

Figs 9-13. Ulnaria ferefusiformis sp. nov. SEM: $(9,12,13)$ are external views, $(10,11)$ are internal views; $(9)$ central are with "ghost striae" evident in the middle of the valve. Striae are uniseriate and alternate on either side of the evident sternum. $(10,11)$ valve apices with distinct rimoportulae and ocellulimbi present. Round areolae are scattered across the valve. $(12,13)$ apices, with round areolae and round opening of rimoportula present. Ocellulimbus is restricted to the valve mantle. Scale bar $2 \mu \mathrm{m}(9,12), 1 \mu \mathrm{m}(10,11,13)$.

molecular data with using more species shown that $U l$ naria is a close related but independent branch from Fragilaria sensu stricto, that supported data given by Meduin et al. (2012).

\section{Taxonomy of new species}

The species that most resembles Ulnaria ferefusiformis sp. nov. is $U$. acus (KütZing) AbOAL 2003 according to various "second hand" concepts of other authors, except that of KüTZING (1844), original describer of this taxon. The basionym Synedra acus KüTZING 1844 has been neotypified recently by LANGE-BERTALOT \& UlRICH (2014). Since the holotype material from "Hamburger Moor", the only location mentioned in KüTZING's protologue. is not available the only other Herbarium number authorized by KüTZING containing

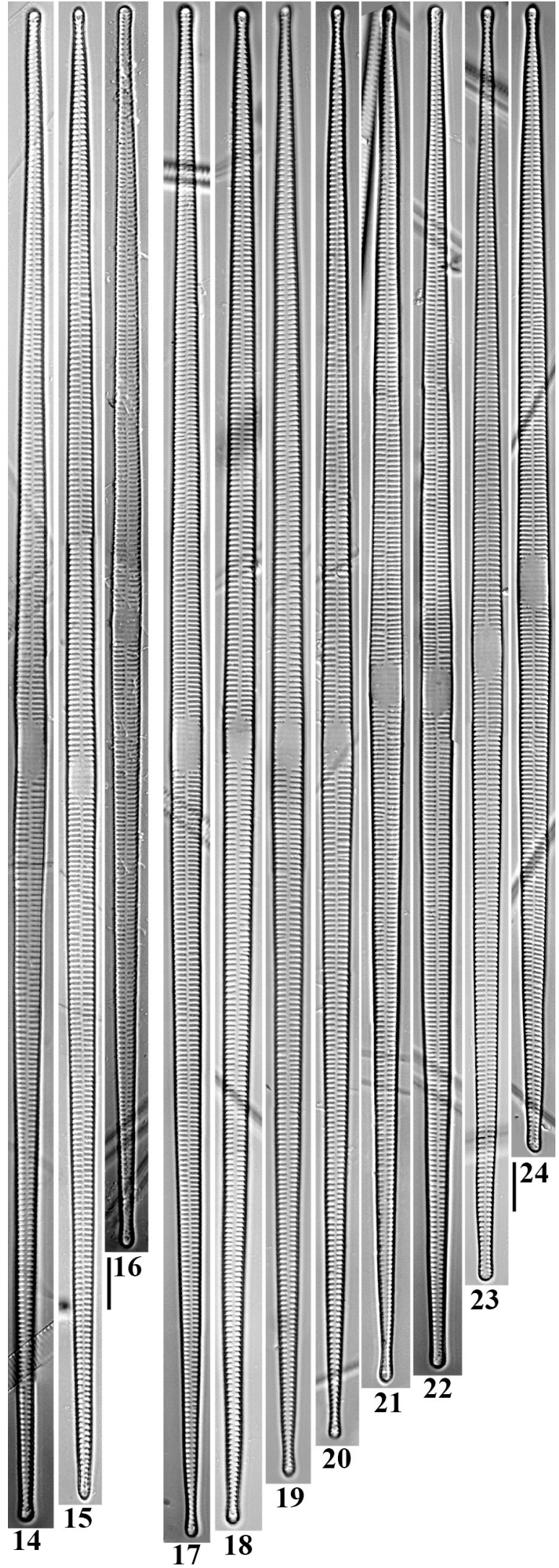

Figs 14-24. Ulnaria pilum sp. nov. LM: (14-16) valves from strain B155, (17-24) valves from strain B160. Scale bar $10 \mu \mathrm{m}$. 
Synedra acus is no. 401 from Falaise, France, collected and sent to KÜtZING by DE BRÉBISSON. It is prepared in slide B.M. no. 18305 with several specimens conforming to KÜTZING's protologue. However, although identified by Kützing as $S$. acus it cannot be lectotypified but just neotypified, since this material was not listed in the original description by him. These specimens are 95-102 $\mu \mathrm{m}$ long, 4.6-5.0 $\mu \mathrm{m}$ broad proximally, resulting in a length-to-breadth ratio of about 20 . Stria density is $11.5-13.0$ in $10 \mu \mathrm{m}$ proximally, becoming 13-15 near the ends. Ulnaria acus differs from $U$. ferefusiformis sp. nov. mainly by valve outlines which are not fusiform. Outline more similar to our new species can be found in Ulnaria grunowii LANGE-BerTALOT \& ULRICH (2014), but these are narrower on average (2.7$4.5 \mu \mathrm{m}$; LANGE-Bertalot \& Ulrich 2014). The valves taper gradually from the center to the ends without a parallel or concave central part. The stria density of this species is similar near the cener of the valve, being $12-13$ in $10 \mu \mathrm{m}$, but becomes more dense towards the apices, 14-16 / $10 \mu \mathrm{m}$.

Ulnaria ferefusiformis sp. nov. is similar to $\mathrm{SK}_{\mathrm{K}}$ ABTICHEWSKY's (1960) and POPOVSKAYA et al.'s (2002) concept of Synedra acus from Lake Baikal. PopovsKAYA et al. (2002) gave the measurements for Synedra acus with a range for length of 90-250 $\mu \mathrm{m}$ and of 4-5 $\mu \mathrm{m}$ for breadth. He recorded 12-14 striae in $10 \mu \mathrm{m}$. These data agree with measurements as given by $\mathrm{SK}_{\mathrm{K}}$ ABITSHEWSKY (1960) with the same length and number of striae and breadth 4.5-5 $\mu \mathrm{m}$. Our data about $U$. ferefusiformis sp. nov. conforms with data cited above, except it is shorter, with length measured at 76-152 $\mu \mathrm{m}$ (see Table 1). Drawing given by SKaBITSCHEwSKY (1960: 86) and TEM pictures from PoPOVSKAYA et al. (2002: 56, 1-3) conform to the valve morphology studied by us on the basis valve morphology and quantitative characters (see Table 1).

$U$. pilum sp. nov. is characterized by very narrow and longer valves. On the basis of these features, our new described species is similar to two taxa known from Lake Baikal, these are Synedra ulna var. danica (KütZING) Grunow (=S. ulna subsp. danica (KütZING) SkABITSChewSKy) and $S$. acus var. radians (KÜTZING) Hustedt (=S. acus subsp. radians (KütZING) SKABITSCHEWSKY). These two infraspecific taxa share the same longer valves with U. pilum sp. nov. However, published data about $S$. ulna var. danica and S. acus var. radians do not allow to us associate these taxa with $U$. pilum sp. nov. as they differ with respect to valve breadth and striae number (see Table 1). Synedra ulna var. danica is similar to U. pilum sp. nov. in terms of valve breadth, but our species differs by having a fewer striae per $10 \mu \mathrm{m}$. Report of wider valves of $S$. ulna var. danica given in PopovskAYA et al. (2002) as compared to other references (see Table 1) is possibly a mistake, and this contention is supported by our measurement of valves from published resources (see Table 1). Synedra acus var. radians differs from U. pilum by wider valves
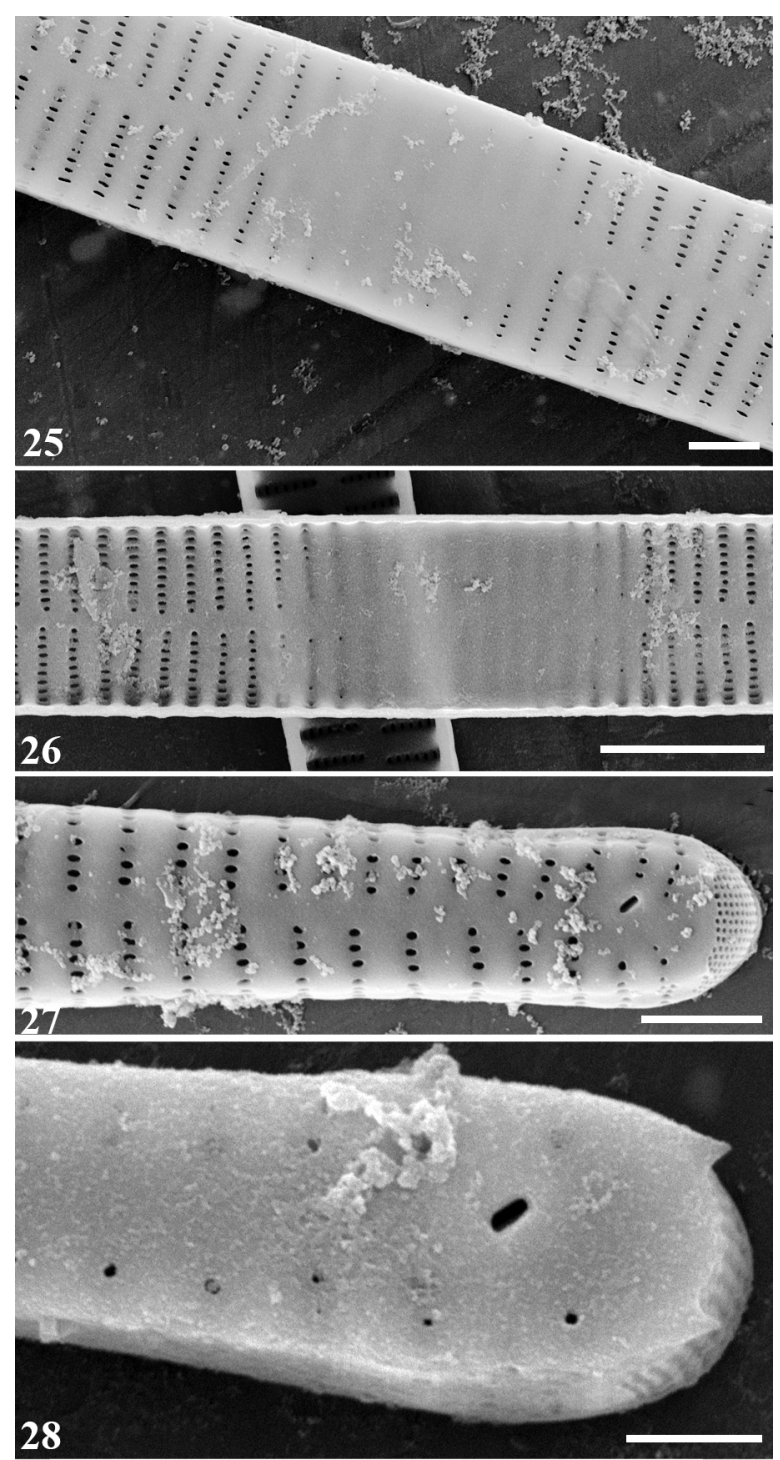

28

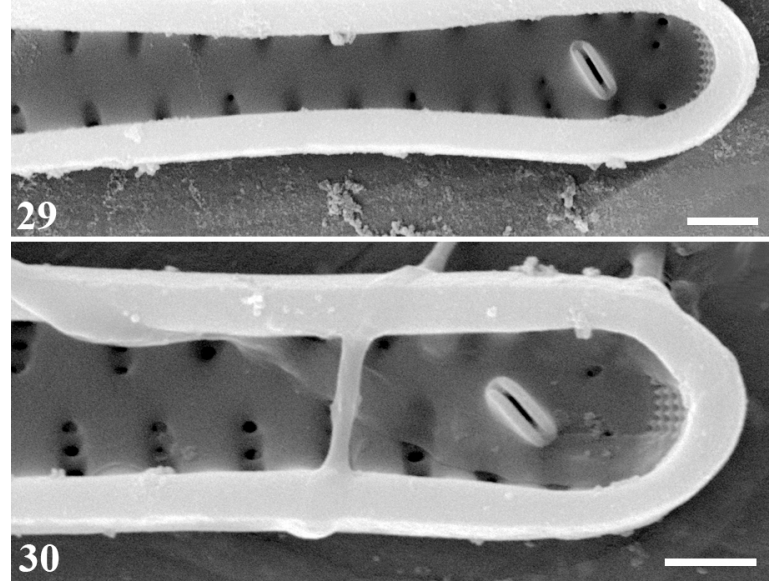

Figs 25-30. Ulnaria pilum sp. nov. SEM: $(25,27,28)$ external views. $(26,29,30)$ internal views. (25) central are showing "ghost straie" and rectangular area. Uniseriate striae are opposite across the distinct central sternum. (26) central area. Unornamented central are is distinct. Areolae are elliptical in shape. $(27,28)$ apices elongated opetinct. Areolae are elliptical in shape. $(27,28)$ apices elongated ope-
ning of rimoportulae angled relative to the central sternum. Pore field extends barely from the mantle onto the valve face and has rounded porelli. Two small spines are evident at the apex in Fig. 28. $(29,30)$ apices, with thickened, raised rimoportulae positioned at an oblique angle relative to the central sternum. A pseudoseptum appears to be present. Porelli are located on the mantle of the valve. Scale bar $2 \mu \mathrm{m}$ $(25,27), 5 \mu \mathrm{m}(26), 1 \mu \mathrm{m}(28,29,30)$. 


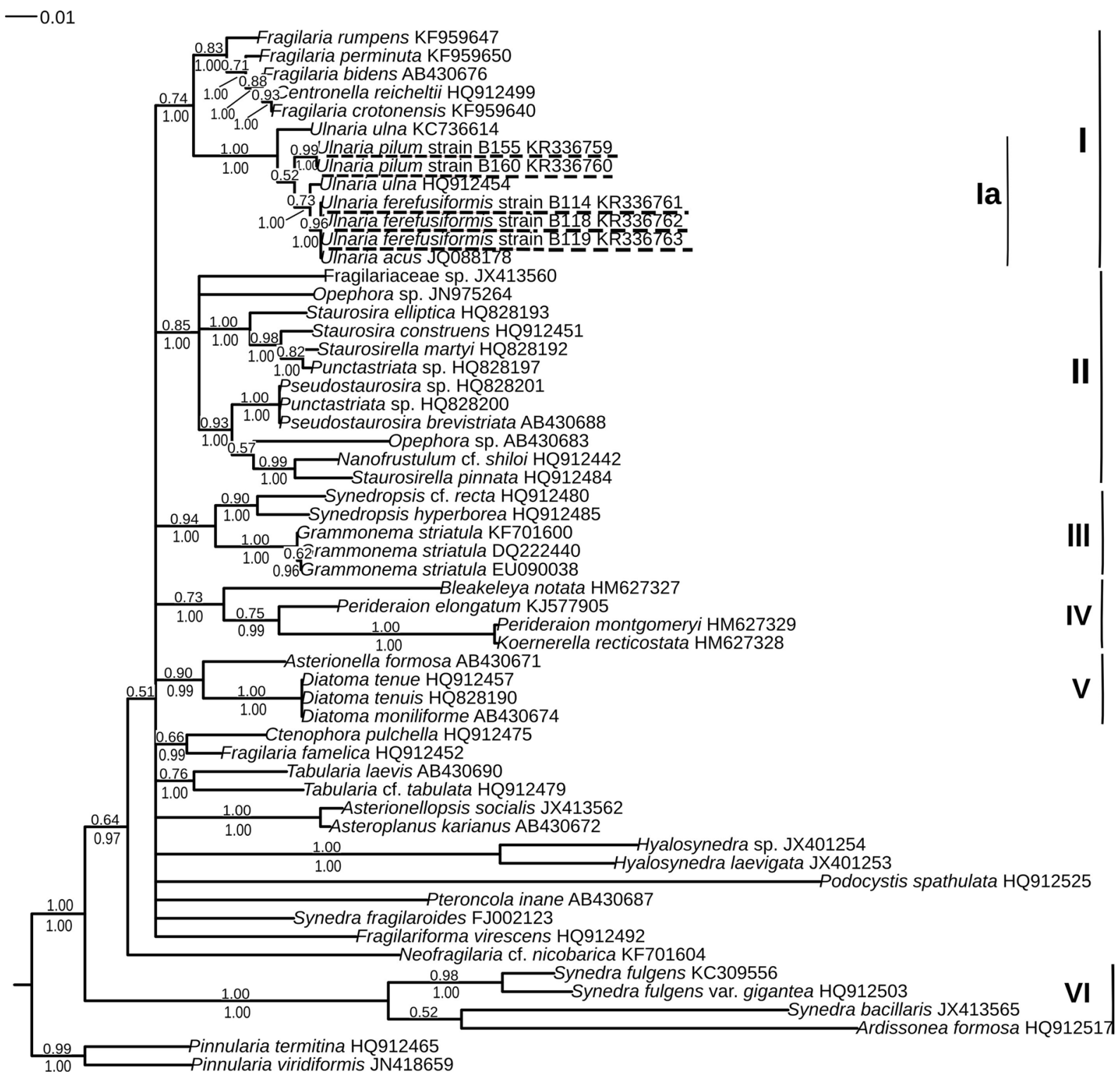

Fig. 31. Phylogenetic analysis based on partial $r b c \mathrm{~L}$ gene. The tree shown is the ML tree. Values above vertical lines are bootstrap support for the ML analyses $(<0.5$ are not shown), Values below vertical lines are BI posterior probabilities $(<0.9$ are not shown). Species analyzed in this study are underlined.

and large number of striae in $10 \mu \mathrm{m}$ (see Table 1). It is not excluded that diversity of planktonic Ulnaria in Lake Baikal is higher that observed previously and that different, closely-related taxa can occur as sympatric cryptic or pseudocryptic populations. Understanding of this phenomenon needs in comprehensive molecular investigation of planktonic Ulnaria from all parts of Lake Baikal. Presence of sympatric populations in diatoms was shown by Амато et al. (2007).

Another species closely-related to U. pilum sp. nov. is Ulnaria ulna. Recently an epitype of Bacillaria ulna Nitzsch 1817 (syn. Synedra ulna (Nitzsch) EHRENBERG syn. Fragilaria ulna (NitzSCH) LANGE-BERTALOT) has been selected, based on a particular line drawing in the protologue of that taxon chosen as lectotype by Lange-Bertalot \& Ulrich (2014). Specimens of the epitype population are likewise needle-shaped,
230-320 $\mu \mathrm{m}$ long, 5.2-6.5 $\mu \mathrm{m}$ broad proximally, 3-4 $\mu \mathrm{m}$ distally below the weakly subcapitate apices; length-to-breadth ratio is $17-50$; stria density $8.5-9.5$ / $10 \mu \mathrm{m}$, areola density $28-33$ in $10 \mu \mathrm{m}$; a central area is not developed (LANGe-Bertalot \& Ulrich 2014). By these data $U$. ulna and U. pilum sp. nov. are similar but not the same. Different are stria- and areola densities and, mainly, the outlines of the distal parts of valves, which are conspicuously less narrowed subapically in $U$. ulna. The slightly inflated subcapitate apices are 3.50-3.75 $\mu \mathrm{m}$ broad (vs. 2.2-2.6). Ulnaria delicatissima (W. Smith) Aboal et Silva (syn. Fragilaria delicatissima (W. Smith) LANGe-Bertalot) is distinguished from $U$. pilum sp. nov. by having narrower valves proximally, about $4 \mu \mathrm{m}$ as far as lectotypified specimens are concerned. 
ACKNOWLedGements

Initial phases of this work, including the gathering of samples and establishing cultures, were supported by Russian President Foundation (MK-1128.2014.4). The publication is based on research carried out with financial support provided by the Russian Science Foundation (14-14-00555).

\section{REFERENCES}

Abarca, N.; Jahn, R.; Zimmermann, J. \& EnKe, N. (2014): Does the cosmopolitan diatom Gomphonema parvulum (Kützing) Kützing have a biogeography? - PLoS ONE 9: 1-18.

Amato, A.; Kooistra, W.H.C.F.; Levialdi Ghiron, J.H.; Mann, D.G.; Pröschold, T. \& Montresor, M. (2007): Reproductive isolation among sympatric cryptic species in marine diatoms. - Protist 158: 193-207.

Annenkov, V.V.; Basharina, T.N.; Danilovtseva, E.N. \& Grachev, M.A. (2013): Putative silicon transport vesicles in the cytoplasm of the diatom Synedra acus during surge uptake of silicon. - Protoplasma 250: $1147-1155$.

Annenkov, V.V.; Danilovtseva, E.N.; Zelinskiy, S.N.; Basharina, T.N.; Safonova, T.A.; Korneva, E.S.; Likhoshway, Ye.V. \& Grachev, M.A. (2010): Novel fluorescent dyes based on oligopropylamines for the in vivo staining of eukaryotic unicellular algae. Analytical Biochemistry 407: 44-51.

Annenkov, V.V.; Kozlov, A.S.; Danilovtseva, E.N.; Basharina, T.N. \& Petrov, A.K. (2013): Dissection of the frustules of the diatom Synedra acus under the action of picosecond impulses of submillimeter laser irradiation. - European Biophysics Journal 42: 587-590.

Basharina, T.N.; Danilovtseva, E.N.; Zelinskiy, S.N.; Klimenkov, I.V.; Likhoshway, Ye.V. \& Annenkov, V.V. (2012): Influence of chemical analogues of silicon on the growth of diatom Synedra acus. - Silicon 4: 239-249.

Bazinet, A.L., \& Cummings, M.P. (2008): The Lattice Project: a grid research and production environment combining multiple grid computing models. Pages 2-13. - In: Weber, M. H. W. (ed.): Distributed \& Grid Computing - Science Made Transparent for Everyone. Principles, Applications and Supporting Communities. -378 pp., Rechenkraft.net, Marburg

Compère, P. (2001): Ulnaria (Kützing) Compère, a new genus name for Fragilaria subgen. Alterasynedra Lange-Bertalot with comments on the typification of Synedra Ehrenberg. - In: JAHN, R.; KocIOLEK, J.P.; WitKowski, A. \& COMPĖRE, P. (eds): Lange-BertalotFestschrift: Studies on Diatoms. Dedicated to Prof. Dr. Dr. h.c. Horst Lange-Bertalot on the occasion of his 65th Birthday. - pp. 97-102, A.R.G. Gantner Verlag. K.G., Ruggell.

Darriba, D; Taboada, G.L.; Doallo, R.; Posada, D. (2012): jModelTest 2: more models, new heuristics and parallel computing. - Nat. Methods 9: 772.

De Queroz, K. \& Gauthier, J. (1994): Towards a phylogenetic system of biological nomenclature. - Trends in Ecology and Evolution 9: 27-31.

Galachyants, Y.P.; Morozov, A.; Mardanov, A.V.; BeletSKY, A.V.; Ravin, N.V.; Petrova, D.P. \& Likhoshway, Y.V. (2012): Complete chloroplast genome sequence of freshwater araphid pennate diatom alga Synedra acus from Lake Baikal. - Int. J. Biol. 4: 27-35.

Grachev, M.; Sherbakova, T.; Masyukova, Yu. \& LikhoshWAY, YE.V. (2005): A potential zinc-binding motif in silicic acid transport proteins of diatoms. - Diatom Research 20: 409-411.

Guillard, R.R.L. \& Lorenzen, C.J. (1972): Yellow-green algae with chlorophyllide c. - Journal of Phycology 8: $10-14$.

HaLl, T.A. (1999): BioEdit: a user-friendly biological sequence alignment editor and analysis program for Windows 95/98/NT. - Nucleic Acids Symp 4: 95-98.

Hampton, S.E.; Gray, D.K.; Izmest'eva, L.R.; Moore, M.V. \& OzERSKY, T. (2014): The rise and fall of plankton: long-term changes in the vertical distribution of algae and grazers in Lake Baikal, Siberia. - PLOS ONE 9: 1-10.

КАтон, K. \& Тон, H. (2010): Parallelization of the MAFFT multiple sequence alignment program. - Bioinformatics 26: 1899-1900.

Kermarrec, L.; Franc, A.; Rimet, F.; Chaumeil, P.; Humbert, J. F. \& Bouchez, A. (2013): Next-generation sequencing to inventory taxonomic diversity in eukaryotic communities: a test for freshwater diatoms. - Molecular Ecology Resources 13: 607-619.

Kharitonenko, K.V.; Bedoshvili, Ye.D. \& Likhoshway, YE.V. (2015): Changes in the micro- and nanostructure of siliceous valves in the diatom Synedra acus under the effect of colchicine treatment at different stages of the cell cycle. - Journal of Structural Biology 190: 73-80.

Kociolek, J.P.; KulikovskiY, M. \& Solak, C.N. (2013): The diatom genus Gomphoneis Cleve (Bacillariophyceae) from Lake Baikal, Russia. - Phytotaxa 154: 1-37.

Kulikovskiy, M.S. \& Kociolek, J.P. (2014): The diatom genus Gomphonema Ehrenberg from Lake Baikal. I. Morphology and taxonomic history of two endemic species. - Nova Hedwigia. Beiheft 143: 507-518.

Kulikovskiy, M.S.; Witkowski, A. \& Khursevich G.K. (2012c): Encyonema horstii sp. nov., a species of unusual valve outline from Pleistocene deposits of Lake Baikal. - Nova Hedwigia, Beiheft 141: 365-374.

Kulikovskiy, M.; Gusev, E.; Andreeva, S. \& Annenkova, N. (2014a): Phylogenetic position of the diatom genus Geissleria Lange-Bertalot \& Metzeltin and description of two new species from Siberian mountain lakes. - Phytotaxa 177: 249-260.

Kulikovskiy, M.; Lange-Bertalot, H.; Metzeltin, D. \& WitKsowski, A. (2012b): Lake Baikal: Hotspot of endemic diatoms. - Iconographia Diatomologica 23: $1-607$.

Kulikovskiy, M.; Lange-Bertalot, H. \& Witkowski, A. (2013): Gliwiczia gen. nov., a new achananthoid diatom genus with description of four species new for science. - Phytotaxa 109: 1-16.

Kulikovskiy, M.; Lange-Bertalot, H.; Witkowski, A.; Khursevich, G.K. \& KocioleK, J.P. (2015a): Description of Eunotia species (Bacillariophyta) new to science from Lake Baikal with comments on morphology and biogeography of the genus. - Phycologia 54: 222-231.

Kulikovskiy, M.S.; Lange-Bertalot, H.; Khursevich, G.K. \& Kuznetsova, I.V. (2012a): New diatom species of the genus Eolimna (Bacillariophyceae) from Lake Baikal. - Novosti sist. nizh. rast. 46: 46-51. 
Kulikovskiy, M.S.; Lange-Bertalot, H.; WitKowski, A. \& Kuznetsova, I. (2014b): Description of four species belonging in Cavinula D.G. Mann \& Stickle from Lake Baikal with notes on family Cavinulaceae D.G. Mann in Round et al. 1990. - Nova Hedwigia 99: 487-499.

Kulikovskiy, M.S.; LANGe-Bertalot, H.; WitKowski, A. \& KhuRSEvich, G.K. (2011): Achnanthidium sibiricum (Bacillariophyta), a new species from bottom sediments in Lake Baikal. - Algological Studies 136/137: 77-87.

Kulikovskiy, M.S.; Lange-Bertalot, H.; Witkowski, A.; Khursevich, G. \& Kuznetsova, I. (2015b): Typification of diatoms from Lake Baikal. I. Some species described by A.P. Skabitschewsky. - Nova Hedwigia 100: 215-223.

Lange-Bertalot, H. \& Ulrich, S. (2014): Contributions to the taxonomy of needle-shaped Fragilaria and $U l$ naria species. - Lauterbornia 78: 1-73.

Losic, D.; Mitchell, J.G. \& Voelcker, N.H. (2009): Diatomaceous lessons in nanotechnology and advanced materials. - Adv. Mater. 21: 2947-2958.

MacKay, A.W.; Flower, R.J.; KuZmina, A.E.; Granina, L.Z.; Rose, N.L.; Appleby, P.G.; Boyle, J.F. \& Battarbee, R.W. (1998): Diatom succession trends in recent sediments from Lake Baikal and their relation to atmosphere pollution and to climate change. - Phil. Trans. R. Soc. Lond. B. 353: 1011-1055.

Medlin, L.; YANG, I. \& SATo, S. (2012): Evolution of the diatoms. VII. Four gene phylogeny assesses the validity of selected araphid genera. - Nova Hedwigia. Beiheft 141: 505-514.

Moore, M.V.; Hampton, S.E.; Izmest'eva, L.R.; Silow, E.A.; Peshrova, E.V. \& Pavlov, B.K. (2009): Climate change and the world's "Sacred Sea" - Lake Baikal, Siberia. - BioScience 59: 405-417.

Popovskaya, G.I. \& GenKal, S.I. (1998): To ecology and morphology of Baikalian Synedra acus subsp. radians (Kütz.) Skabitsch. (Bacillariophyta). - Inland Water Biology 1: 92-95.

Popovskaya, G.I.; Genkal, S.I. \& Likhoshway Ye. V. (2002): Diatoms of the plankton of Lake Baikal. - 168 pp., Nauka, Novosibirsk.

Popovskaya, G.I.; Genkal, S.I. \& Likhoshway Ye. V. (2011): Diatoms of the plankton of Lake Baikal. - 186 pp., Nauka, Novosibirsk.

Ravin, N.V.; Galachyants, Yu.P.; Mardanov, A.Y.; BeletSky, A.V.; Petrova, D.P.; Sherbakova, T.A.; ZaKharova, Yu.R.; LikhoshwaY, Ye.V.; Skryabin, K.G. \& Grachev, M.A. (2010): Complete sequence of the mitochondrial genome of a diatom alga Synedra acus and comparative analysis of diatom mitochondrial genomes. - Current Genetics 56(3): 215-223.

Ronquist, F., HuelsenBeCK, J.P. (2003): MrBayes 3: Bayesian phylogenetic inference under mixed models. Bioinformatics 19: 1572-1574.

Safonova, T.A.; Annenkov, V.V.; Chebykin, E.P.; DanilovtSeVa, E.N.; Likhoshway, Ye.V. \& Grachev, M.A. (2007): Aberration of morphogenesis of siliceous frustule elements of the diatom Synedra acus in the presence of Germanic acid. - Biochemistry Moscow 72: $1261-1270$.

SkABITSCHEWSKY, A.P. (1960): Planktonic diatoms of freshwater ecosystems of USSR. - 349 pp., Moscow State University, Moscow.
Tamura, K.; Peterson, D.; Peterson, N.; Stecher, G.; Nei, M. \& Kumar, S. (2011): MEGA5: Molecular Evolutionary Genetics Analysis using maximum likelihood, evolutionary distance, and maximum parsimony methods. - Mol. Biol. Evol. 28: 2731-2739.

Theriot, E.C.; Ashworth, M.; Ruck, E.; Nakov, T. \& JanSEN, R.K. (2010): A preliminary multigene phylogeny of the diatoms (Bacillariophyta): challenges for future research. - Plant Ecology and Evolution 143: 278-296.

Vishnyakov, V.S.; Kulikovskiy, M.S.; Genkal, S.I.; DoroFEYUK, N.I.; LANGe-Bertalot, H. \& KuZnetsova, I.V. (2014): Taxonomy and geographical distribution of the diatom genus Epithemia Kützing in water bodies of Central Asia. - Inland Water Biology 7: 318-330.

Zakharova, Yu.R.; Adel'shin, R.V.; Parfenova, V.V.; BedoShVili, Ye.D. \& Likhoshway, Ye.V. (2010): Taxonomic characterization of the microorganisms associated with the cultivable diatom Synedra acus from Lake Baikal. - Microbiology 79: 679-687.

(C) Czech Phycological Society (2016)

Received May 7, 2015

Accepted June 3, 2015 